\title{
Strategi pemenangan dalam pemilihan kepala daerah
}

\author{
Head of regency election winning strategy
}

\author{
Bowo Sugiarto, Oktafiani C Pratiwi, Andi A Said Akbar \\ Jurusan Ilmu Politik, FISIP, Universitas Jenderal Soedirman, Purwokerto \\ bowosugiarto@gmail.com, oktafiani.cp@gmail.com, alisaid_politik@yahoo.com
}

\begin{abstract}
Based on empirical case of Husein and Budhi's victory in the Banyumas local election in 2013, this article gives contribution to the study of political communication, especially on the issue of the campaign. The context of this article is the incumbent head of regency candidate, who had more chances to win, was defeated by the other candidate. The research method used was descriptive qualitative. This research was conducted in Banyumas. The data collected by interview and informant were chosen by purposive sampling technique. The aim of this research is to report Husein-Budhi campaign team and political party members. This article includes analysis of the Husein and Budhi's strategy to win the local election and the contextual factor supported their winning. Those strategies encompass areas of party consolidation, segmentation, targeting, positioning, and the image of candidate Those strategies are the creation of images that he is not part of the incumbents so he cannot be in charged by any criticism to the local government, the campaign issues that correspond with the weakness of the potential rival and the campaign objectives, the party rooting by involving elements of civil society and the party consolidation which is included from the candidacy process to campaign by employing local legislative candidates. The contextual factor is the information about the potential rival candidate's weakness that caused voters' disappointment to him. In conclusion, the future head of regency can win an election by doing the same strategy as Husein-Budhi.
\end{abstract}

Keywords: campaign, local election, winning strategy

\begin{abstract}
Abstrak
Dengan berdasarkan kasus empiris tentang pemenangan pasangan Husein-Budhi dalam pemilihan kepala daerah Kabupaten Banyumas tahun 2013, artikel ini memberikan kontribusi bagi kajian komunikasi politik, khususnya tentang kampanye. Metode penelitian kualitatif deskriptif. Penelitian ini mengambil lokasi di Kabupaten Banyumas. Metode koleksi data adalah wawancara dan metode dokumenter. Informan dipilih berdasarkan metode purposive sampling. Sasaran dalam penelitian ini meliputi tim sukses pasangan Husein-Budhi dan pengurus Partai. Artikel ini mencakup analisis tentang strategi yang digunakan oleh Husein-Budhi dalam memenangkan pemilukada tersebut dan faktor kontekstual yang mendukung kemenangan itu. Strategi kemenangan itu meliputi area konsolidasi partai, segmentasi, targeting, positioning, dan citra kandidat. Strategi kemenangan pasangan ini terdiri dari pembentukan citra diri bukan sebagai bagian dari pertahana sehingga kritik terhadap kekurangan pemerintahan yang ada tidak mengenainya juga, pemilihan isu kampanye yang sesuai dengan kelemahan lawan dan sasaran kampanye, pengakaran partai dengan menggandeng pelbagai elemen masyarakat sipil dan konsolidasi internal partai yang dilakukan dari proses kandidasi sampai kampanye dengan melibatkan calon anggota legislatif. Faktor kontekstualnya adalah informasi tentang kekurangan lawan paling potensial, yaitu calon bupati petahana, yang menyebabkan kekecewaan para pemilih terhadapnya. Dapat disimpulkan bahwa calon bupati petahana dapat memenangkan pemilikada jika melakukan strategi seperti yang dilakukan oleh pasangan Husein-Budhi.
\end{abstract}

Kata Kunci: kampanye, pemilukada, strategi pemenangan

\section{Pendahuluan}

Pemilihan umum kepala daerah (pemilukada) langsung pada era reformasi mengindikasikan adanya peningkatan kualitas demokrasi di Indonesia. Kadar demokrasi suatu negara ditentukan antara lain 
oleh seberapa besar peranan masyarakat dalam memilih pejabat negara. Semakin banyak pejabat negara baik tingkat nasional maupun di tingkat daerah yang dipilih secara langsung oleh rakyat, semakin tinggi kadar demokrasi dari negara tersebut, paling tidak, dalam tataran prosedural. Hal tersebut berkorelasi positif dengan konsep otonomi daerah dan desentralisasi, di mana kadar partisipasi rakyat semakin tinggi, baik dalam memilih pejabat publik, mengawasi perilakunya, maupun dalam menentukan arah kebijakan publik. Mengutip pendapat Robert Dahl "bahwa demokratisasi pada tingkat nasional hanya mungkin terbangun jika demokrasi juga berlangsung pada tingkat lokal" (Fitriyah 2005: 297).

Ada sebuah fenomena menarik dalam ajang pemilukada yaitu terdapatnya petahana yang sebagian besar menang dalam setiap persaingan menduduki kursi orang nomor satu di daerah. Hal tersebut terjadi karena, selain memiliki dukungan beberapa jaringan dan mesin politiknya yang cukup solid, kandidat petahana ini mempunyai image position sebagai pejabat yang popular di mata publik. Apalagi jika proses tersebut ditopang dengan kinerja figur yang positif tentunya akan semakin memperkuat korelasi antara pemilihan dan calon kandidat dalam hal memperoleh kemenangan (Firmanzah 2010: 229). Fenomena ikutnya calon petahana juga terjadi dalam pemilukada langsung Kabupaten Banyumas yang telah berlangsung pada tanggal 17 Februari 2013.

Pemilukada langsung Kabupaten Banyumas diikuti oleh enam pasangan calon yaitu MardjokoGempol (didukung oleh Golkar, Hanura, dan Gerindra), Husein-Budhi (dicalonkan oleh Partai Demokrasi Indonesia Perjuangan (PDIP) dan Partai Persatuan Pembangunan (PPP), Muhson-Hendri (disokong oleh Partai Kebangkitan Bangsa (PKB) dan Partai Demokrat), Toto-Sae (calon perseorangan), Anteng-Dwi Basuki (calon perseorangan), serta Warman-Winarni (didukung oleh Partai Keadilan Sejahtera (PKS) dan Partai Amanat Nasional (PAN). Dari keenam pasang calon tersebut, dua pasangan calon kepala daerah Kabupaten Banyumas tersebut merupakan calon petahana (incumbent) yang sebelumnya merupakan pasangan bupati dan wakil bupati Banyumas periode 20092013 yaitu Mardjoko-Husein. Di pemilukada Banyumas 2013, Mardjoko-Husein pecah kongsi dan masing-masing maju menjadi calon bupati dengan pasangan lain. Salah satu yang membuat pemilukada Banyumas 2013 menarik untuk diteliti adalah bahwa Mardjoko yang diduga akan menang kembali ternyata kalah oleh Husein hanya dalam satu putaran pemilu saja.

Hasil pemilukada langsung Kabupaten Banyumas menggambarkan perolehan suara yang signifikan bagi pasangan Husein-Budhi. Pasangan yang diusung oleh Partai Demokrasi Indonesia Perjuangan (PDIP) dan Partai Persatuan Pembangunan (PPP) berhasil memperoleh suara 45,43 persen mengalahkan pasangan calon kepala daerah lainnya, yaitu Mardjoko-Gempol (30,31\%), Toto Dirgantoro-Saefuddin (4,06\%), Anteng Tjahyono Widyadi-Dwi Basuki (3,49\%), Muhson-Hendri $(12,87 \%)$, dan Warman-Winarni $(4,69 \%)$.

Pasangan Husein-Budhi yang tak pernah diperhitungkan akan memenangkan pemilukada Banyumas justru mendapat dukungan mayoritas dari para pemilih. Bahkan isu SARA yang sempat muncul menjelang hari pemilihan suara yang digunakan untuk menjatuhkan pasangan Husein-Budhi, yaitu terkait agama yang dianut oleh Budhi yang bukan penganut agama Islam dan asal etnis Budhi yang merupakan keturunan Tionghoa, nyatanya tak mampu menyurutkan keinginan para pemilih untuk tetap memberikan dukungan kepada pasangan ini. Kemenangan pasangan Husein-Budhi dalam pemilukada langsung Kabupaten Banyumas tak bisa lepas dari strategi yang dijalankan oleh tim sukses maupun partai politik yang mengusung pasangan ini.

Berdasarkan paparan latar belakang di atas, artikel ini hendak membahas strategi pemenangan pasangan Husein-Budhi dalam pemilihan kepala daerah Kabupaten Banyumas tahun 2013. Selain itu, akan disinggung juga faktor kontekstual yang mendukung kemenangan pasangan Husein-Budhi. 


\section{Metode Penelitian}

Metode penelitian yang digunakan dalam penelitian ini adalah metode penelitian kualitatif deskriptif. Penelitian ini mengambil lokasi di Kabupaten Banyumas. Metode koleksi data adalah wawancara dan metode dokumenter. Informan dipilih berdasarkan metode purposive sampling. Sasaran dalam penelitian ini meliputi tim sukses pasangan Husein-Budhi dan pengurus Partai Demokrasi IndonesiaPerjuangan (PDI-P) sebagai partai pengusung pasangan Husein-Budhi di tingkat kabupaten dan kecamatan. Sumber data dokumentasi berasal dari arsip, dokumen dan berita di media massa.

\section{Hasil dan Pembahasan}

\section{Pemilukada dan strategi marketing politik}

Ada sejumlah alasan yang memperkuat argumen bahwa pemilukada langsung pantas dilaksanakan, di antaranya adalah sebagai kritik terhadap demokrasi perwakilan yang melahirkan wakil-wakil rakyat yang mengabaikan kepentingan pemilihnya, dan upaya untuk mengutamakan kembali partisipasi rakyat dalam menentukan pilihannya (Romli 2005:279); merupakan prosedur untuk kompetisi politik yang damai, amanat konstitusi UUD 1945, UU No. 32 tahun 2004 dan PP No. 6 tahun 2005, solusi terhadap rekrutmen kepala daerah yang dilakukan oleh DPRD yang melahirkan politik uang, sarana pembelajaran politik bagi warga (Purwoko 2005:7-8); sebagai perwujudan otonomi daerah yang seluas-luasnya (Amirudin \& Bisri 2005:14).

Dalam pelaksanaan pemilukada langsung tersebut, tahapan persiapan ataupun tahapan pelaksanaan diatur oleh KPUD dan untuk selanjutnya akan berpedoman pada PP No. 6 tahun 2005. Dalam PP tersebut dijelaskan bahwa pasangan calon berhak untuk melakukan kampanye sebagai bagian dari tahapan pelaksanaan pemilukada dengan jadwal yang ditentukan oleh KPUD dengan memperhatikan usul dari pasangan calon. Seiring dengan kemajuan teknologi dan komunikasi serta semakin terintegrasinya masyarakat global dan tekanan untuk menerapkan prinsip-prinsip demokrasi, institusi politik pun, termasuk di dalamnya partai politik, membutuhkan pendekatan alternatif dalam kampanye. Dalam konteks inilah marketing sebagai suatu disiplin ilmu yang berkembang di dunia bisnis diasumsikan berguna bagi institusi politik (Firmanzah 2010:127).

Marketing politik merupakan cara untuk merebut hati konstituen dan membuat mereka memilih kandidat yang diinginkan. Persaingan menuntut para kandidat untuk memikirkan cara dan metode yang efektif dalam berkomunikasi dan meyakinkan konstituen bahwa mereka layak dipilih (Cangara 2009:148). Salah satu strategi marketing politik adalah melalui kampanye. Kampanye adalah aktivitas komunikasi yang ditujukan untuk mempengaruhi orang lain agar ia memiliki wawasan, sikap, dan perilaku sesuai dengan kehendak atau keinginan penyebar atau pemberi informasi. Dalam konteks komunikasi politik, menurut Steven Chaffe, kampanye dimaksudkan untuk memobilisasi dukungan terhadap suatu hal atau seorang kandidat (Chaffe dalam Cangara 2009:276). Sedangkan menurut Imawan (Cangara 2009:276) kampanye adalah upaya persuasif untuk mengajak orang lain yang belum sepaham atau belum yakin pada ide-ide yang ditawarkan, agar mereka bersedia bergabung dan mendukungnya.

Menurut Lock dan Harris (Firmanzah 2009:275) kampanye politik terkait erat dengan pembentukan image politik. Dalam kampanye politik terdapat dua hubungan yang akan dibangun, yaitu internal dan eksternal. Hubungan internal adalah suatu proses antara anggota-anggota partai dengan pendukung untuk memperkuat ikatan ideologis dan identitas mereka. Sementara hubungan eksternal dilakukan untuk mengkomunikasikan image yang akan dibangun kepada pihak luar partai, termasuk media massa dan masyarakat. Faktor utama penyebab seseorang bisa meraih kemenangan adalah sejauh mana kemampuannya dalam mencitrakan diri sehingga masyarakat mengenalnya dan bersimpati padanya. Banyak strategi yang bisa dilakukan untuk menjadi pemenang. Ada strategi yang positif (sesuai dengan aturan) dan ada juga yang negatif, seperti: money politic, black campaign, manipulasi suara dan sederet kecurangan lainnya. Di antara strategi yang kerap dimainkan dalam kompetisi 
politik baik pada pemilu anggota legislatif, pilpres atau pemilu kepala daerah adalah mengangkat sebuah opini dan isu yang menyita perhatian publik dan menimbulkan simpati bagi para pemilih. Selain itu, ada juga strategi kampanye dengan menempatkan figur atau tokoh di balik partai, ideologi atau kepentingan, dan janji yang diusung.

\section{Konteks politik di Banyumas}

Sejak dahulu Banyumas dikenal sebagai basis pemilih berideologi nasionalis, khususnya Marhaenis. Pada pemilu pertama di negeri ini, Partai Nasional Indonesia (PNI) berhasil merebut suara terbanyak di kabupaten yang kini memiliki 331 desa/kelurahan itu, yaitu sebanyak 48,57 persen suara. Pada masa Soeharto berkuasa satu-satunya partai yang mewarisi ideologi PNI, yaitu Partai Demokrasi Indonesia (PDI), tidak dapat mengungguli Golongan Karya (Golkar). Setelah Orde Baru tumbang, salah satu partai reinkarnasi PDI, yaitu PDI Perjuangan (PDIP) berhasil meraih suara terbanyak pada pemilu 1999 dengan jumlah suara sebanyak 47,49 persen. Dengan perolehan jumlah suara tersebut, PDIP mampu menempatkan 19 orang kadernya di DPRD Banyumas.

Pada pemilu 2004, meskipun tetap menjadi yang teratas, perolehan suara PDIP menurun cukup signifikan pada pemilu 2004 yaitu hanya sebanyak 36,56 persen. Penuruan tersebut memaksa PDIP harus puas dengan jumlah 16 kursi anggota dewan saja. Posisi kedua kembali dipegang Golkar dengan jumlah delapan kursi. Pemilu 2004 juga menandai lahirnya kekuatan politik baru, yaitu Partai Demokrat yang berhasil meraih empat kursi. Penurunan suara PDIP kembali terjadi pada pemilu 2009. Partai berlambang banteng ini hanya mampu meraup 26,17 persen suara. Itu berarti partai ini harus kehilangan tiga kursi anggota dewan dari jumlah periode sebelumnya. Meski demikian, mereka tetap sebagai partai yang paling banyak menempatkan wakilnya di DPRD Banyumas. Sementara Partai Demokrat semakin menanjak perolehan jumlah suaranya.

Berdasarkan hasil pemilu 2009 itu, PDIP mempunyai wakil sebanyak 13 orang di DPRD Banyumas. Urutan terbanyak berikutnya adalah Partai Demokrat dan Golkar yang sama-sama memiliki anggota dewan sejumlah tujuh orang. Partai Kebangkitan Bangsa (PKB), Partai Keadilan Sejahtera (PKS) dan Partai Amanat Nasional (PAN) sama-sama menempatkan lima politisinya di DPRD Banyumas. Dengan demikian, sejauh pertimbangannya adalah jumlah kursi di DPRD, PDIP yang berkongsi dengan PPP memiliki peluang yang cukup besar untuk memenangkan calonnya, yaitu Husein-Budhi, dalam pemilukada Banyumas 2013. Meski demikian, peta perolehan kursi di DPRD memang bukan ukuran mutlak. Setidaknya itu yang terjadi pada pemilukada Banyumas 2008. Walaupun perolehan suara PDIP adalah yang terbanyak pada pemilu 2004, akan tetapi partai itu gagal memenangkan calonnya pada pemilukada Banyumas 2008. Pasangan Mardjoko-Ahmad Husein yang menjadi pemenang pada pemilukada tahun itu merupakan calon yang didukung oleh Partai Kebangkitan Bangsa (PKB). Lawan paling potensial Husein-Budhi, pasangan Mardjoko-Gempol, yang didukung oleh tiga partai, yaitu Golkar, Hanura dan Gerindra, justru dianggap memiliki peluang yang lebih besar mengingat posisi Mardjoko sebagai bupati petahana. Dengan posisinya itu, Mardjoko berpotensi untuk memanfaatkan birokrasi demi kepentingan politiknya di pemilukada Banyumas 2013.

\section{Strategi pemenangan}

\section{Konsolidasi partai dan tim sukses}

Perencanaan merupakan bagian yang paling krusial agar tujuan yang diharapkan tercapai. Konsolidasi partai dan tim kampanye merupakan bagian yang tidak bisa terpisahkan baik yang bersifat internal maupun eksternal. Konsolidasi internal yang dilakukan PDIP sebagai partai pengusung pasangan Husein-Budhi dapat dilihat dari tahap penjaringan, pemilihan hingga penetapan pasangan calon kepala daerah Kab. Banyumas. Terpilihnya Husein-Budhi dimulai dari proses survey yang dilakukan oleh DPC PDIP Banyumas dengan mengambil orang-orang di Banyumas yang dianggap tokoh untuk dicek kualitas dan elektabilitas di daerah-daerah pemilihan sampai keluar empat nama, salah satunya adalah nama Ahmad Husein. Penentuan nama-nama calon kepala daerah yang akan disurvey 
dilakukan atas permintaan dari diri sendiri ataupun berdasarkan pengajuan dari masing-masing ranting melalui proses konvensi internal agar proses partisipasi (bottom-up) tetap terjaga. Husein punya kesempatan untuk ikut dalam survey tersebut karena ia adalah salah satu pengurus DPC PDIP Banyumas dan menjabat sebagai Ketua Badan Pemenangan Pemilu, sedangkan Budhi Setyawan merupakan ketua DPC PDIP Banyumas.

Proses penjaringan tersebut menghasilkan satu pasangan calon yaitu Husein-Budhi yang ditetapkan sebagai pasangan calon yang diusung oleh PDIP Banyumas dan didukung oleh PPP Banyumas. Husein-Budhi dipandang sebagai sosok yang tepat untuk memimpin Banyumas dan cenderung bisa diajak kerja sama dalam melakukan perubahan. Soliditas internal dilakukan oleh partai dan tim sukses untuk mengawal rekomendasi dari DPP PDIP agar tetap diberikan pada Husein-Budhi sehingga tidak muncul rekomendasi ganda yang seringkali menggagalkan kemenangan pasangan calon. Rekomendasi dari DPP PDIP disosialisasikan oleh pengurus partai baik di tingkat cabang maupun tingkat ranting. Konsolidasi eksternal dilakukan tim sukses dengan melibatkan aktivis-aktivis Lembaga Swadaya Masyarakat (LSM), pegiat desa, akademisi, organisasi sayap partai, relawan pendukung, wartawan dan pedagang kaki lima (PKL). Keterlibatan aktivis LSM dalam tim sukses bertugas untuk memastikan dukungan dari kelompok-kelompok masyarakat sipil. Pegiat desa dilibatkan sebagai tim sukses untuk memastikan dan meyakinkan masyarakat di level desa bahwa sosok Husein-Budhi layak untuk dipilih karena keberpihakannya pada masyarakat desa. Akademisi juga dilibatkan dalam proses penyusunan visi, misi dan survey. Organisasi sayap partai dilibatkan untuk membantu partai dalam melakukan eksekusi di lapangan. Wartawan dilibatkan terutama dalam hal pemberitaan di media.

Konsolidasi internal partai dilakukan juga melalui koordinasi secara intensif dengan DPP dan DPC PDI-P baik dalam hal bantuan pendanaan yang sifatnya gotong-royong dari para anggota dewan di pusat yang maju dari Dapil Banyumas dan para anggota dewan dari PDIP Banyumas yang harus bertanggung jawab memenangkan Husein-Budhi di daerah pemilihannya. Selain itu, konsolidasi juga dilakukan dengan partai pendukung yakni PPP untuk mensosialisasikan program Husein-Budhi dan memastikan dukungan dari kader dan simpatisan PPP untuk Husein-Budhi. DPP PDI-Perjuangan juga secara intensif memberikan dukungan untuk mengantisipasi kemungkinan terjadinya serangan dari tim Mardjoko, misalnya kecurigaan penggunaan intelijen.

\section{Segmentasi, targetting, positioning}

Segmentasi pada dasarnya digunakan untuk mengenal lebih jauh kelompok-kelompok khalayak yang berguna untuk mencari peluang, menggerogoti kelompok lawan berdasarkan kecenderungan pilihan, preferensi, keinginan, cita rasa, gaya hidup, sistem nilai bahkan sampai pada persoalan pribadi. Segmentasi yang disasar oleh tim sukses Husein-Budhi adalah rakyat kecil. Oleh karena itu, programprogram pembangunan yang dirancang dalam visi misi Husein-Budhi adalah program-program populis yang benar-benar dibutuhkan oleh masyarakat kecil seperti sekolah gratis dan biaya berobat gratis. Pasangan ini tampaknya hendak memanfaatkan momentum kemenangan Joko Widodo (Jokowi)-Basuki Tjahja Purnama dalam Pemilukada Jakarta. Salah satu ide populis Jokowi yang ditiru oleh Husein-Budhi adalah program-program yang konkret dan mudah dipahami oleh warga, misalnya Kartu Jakarta Sehat (KJS). Mereka mengambil alih ide KJS itu dalam program yang mereka beri nama Kartu Banyumas Sehat (KBS). Meskipun kita dapat meletakkan program KBS dalam konteks euforia kemenangan Jokowi di Jakarta, akan tetapi program ini sebenarnya memiliki aspek kontekstualnya sendiri. Semasa kepemimpinanya, Mardjoko berkali-kali membatalkan implementasi inisiatif subsidi kesehatan.

Program Husein-Budhi yang lain yang dimaksudkan untuk menyasar pemilih dari kalangan ekonomi lemah adalah pembentukkan Badan Usaha Milik Desa (BUMDes), bantuan pemodalan dan pelatihan wirausaha dan pembatasan toko serba ada (toserba) di desa dan kecamatan. Tampaknya, dengan menawarkan program-program tersebut, pasangan ini hendak menyasar para pemilih di pedesaan. Jika Mardjoko ingin membuka lapangan pekerjaan dengan cara mendatangkan investor, pasangan HuseinBudhi melakukannya dengan cara mendorong kewirausahaan warga desa. Program yang populis ini 
rupanya yang lebih dipilih oleh warga. Program-program populis ini terkait erat dengan isu lain yang diangkat oleh pasangan ini.

Program-program seperti pembentukkan BUMDes dan bantuan pemodalan dan pelatihan wirausaha tidak bisa dipisahkan dengan isu lain yang disampaikan oleh pasangan ini, yaitu pembangunan perdesaan. Program pembentukkan BUMDes itu dimaksudkan sebagai ujung tombak perekonomian perdesaan. Pasangan Husein-Budhi mengiming-imingi pemilih di desa khususnya mereka yang bergerak di bidang pertanian dan perkebunan dengan janji menggeser fokus pembangunan dari kota ke desa. Misalnya, mereka berencana untuk menyusun Peraturan Daerah (perda) yang akan melindungi lahan produktif pertanian dari gerusan pembangunan perumahan yang memang massif dilakukan di masa jabatan Mardjoko. Untuk mendukung program itu, mereka juga berencana membenahi infrastruktur desa, terutama jalan dan irigasi.

Tim Husein-Budhi tidak menyasar PNS di lingkungan pemerintah daerah Kabupaten Banyumas karena sudah dapat dipastikan bahwa PNS dengan jabatan eselon ke atas memilih Mardjoko. Berdasarkan survey awal yang digembar-gemborkan oleh lembaga survey eksternal, Mardjoko memang diposisikan sebagai pasangan yang terkuat untuk menjadi pemenang. Mayoritas PNS mendukung Mardjoko karena mereka ketakutan akan dimutasi olehnya. Ketakutan itu muncul karena selama pemerintahan Mardjoko PNS yang tidak loyal kepadanya akan dimutasi. Oleh karena itu, terkait dengan soal birokrasi, pasangan Husein-Budhi memilih pendekatan yang lebih lunak yaitu cukup dengan menyuarakan ide-ide yang mendukung profesionalisme birokrasi. Ide-ide yang mendorong pejabat politik bekerja sama secara sehat dan produktif dengan birokrasi. Dalam kampanyenya, mereka bahkan berkomitmen untuk membatasi rotasi birokrasi.

Targetting digunakan untuk memilih salah satu atau beberapa segmen yang akan dibidik untuk mencapai sasaran obyektif. Targetting juga dilakukan untuk memfokuskan kegiatan kampanye dan isu yang dibuat. Khalayak sasaran yang dipilih oleh tim sukses kandidat adalah individu-individu yang masih ada pada posisi belum memiliki pilihan terhadap salah satu pasangan calon baik pemilih lama maupun pemilih pemula. Kampanye juga dilakukan kepada basis massa pendukung utama untuk memastikan bahwa para loyalis PDIP dan PPP akan memilih Husein-Budhi. Peran partai dalam kemenangan pasangan Husein-Budhi pada pemilihan kepala daerah langsung Kabupaten Banyumas tidak bisa dianggap sepele. Jika di banyak pemilihan kepala daerah, partai tidak banyak berperan dalam melakukan konsolidasi pengurus maupun massa dari level tertinggi (DPC) sampai terendah (desa), tidak demikian yang terjadi di Banyumas. Partai pengusung dalam hal ini PDIP betul-betul bekerja dengan memaksimalkan mesin politik partai. Bahkan untuk menarik massa pemilih dan meyakinkan pemilih, terutama dari para pemilih PDIP dan PPP, tim sukses mendatangkan ketua umum PDIP Megawati Sukarno Putri dan pengurus DPP PDIP lainnya seperti Puan Maharani dan Tjahjo Kumolo, serta tokoh NU Yeni Wahid.

Positioning merupakan atribut pembeda yang membedakan satu kandidat dengan kandidat lainnya. Atribut pembeda yang melekat dalam diri Husein-Budhi melalui slogan kampanye "Husein berBudhi" yang diusung oleh pasangan ini menjadi pembeda dengan kandidat lain yang menyentuh hati para pemilih. Tim sukses pasangan ini menerjemahkan slogan kampanye tersebut untuk melihat sosok Husein yang memiliki pribadi yang santun baik dalam berperilaku maupun berbahasa. Bahkan di dalam setiap kampanye politiknya, tim sukses mengatur sedemikian rupa mulai dari busana yang disesuaikan dengan konteks sosial konstituen hingga gaya bicara maupun materi yang diorasikan agar bisa memperoleh simpati dari para calon pemilih. Positioning lainnya adalah bahwa di mata masyarakat, sosok Husein 'seolah-olah' adalah sosok yang dikuya-kuya oleh Mardjoko karena tindakannya yang seringkali bersebarangan antara Mardjoko dan dia mampu mengatasi masalah yang terjadi di masyarakat.

\section{Pencitraan pasangan calon bupati}

Terbatasnya waktu kampanye yang disediakan oleh Komisi Pemilihan Umum memaksa pasangan calon kepala daerah dan calon wakil kepala daerah beserta tim kampanyenya untuk merencanakan 
strategi politik secara efektif agar dapat menjangkau seluruh masyarakat. Jenis komunikasi yang dianggap sesuai untuk memenuhi kebutuhan itu adalah komunikasi massa, sehingga saluran komunikasi yang banyak digunakan adalah media massa. Media massa dimanfaatkan oleh tim sukses dari setiap pasangan calon kepala daerah untuk menciptakan citra diri positif dari pasangan calon tersebut di masyarakat. Proses pencitraan lewat media massa itu dilakukan berulang-ulang sehingga pada akhirnya akan melekat di pikiran pemilih dan mendorong mereka untuk memilih calon kepala daerah tersebut.

Salah satu media massa yang dimanfaatkan untuk kampanye pasangan calon kepala daerah Banyumas (Husein-Budhi) pada pemilukada Banyumas tahun 2013 adalah 'Satelit Post'. Harian ini merupakan sebuah koran lokal yang tergolong baru dalam dunia penerbitan di Banyumas sehingga dianggap masih murni dari pengaruh rezim lokal yang berkuasa. Satelit Post memposisikan diri sebagai media yang sering mengkritisi pelayanan publik di Banyumas. Hal ini, secara tidak langsung menempatkan Satelit Post berada di pihak oposisi. Kelebihan lain yang dimiliki oleh Satelit Post adalah kemampuan untuk mengemas Husein-Budhi sebagai sosok pasangan calon kepala daerah yang 'seolah-olah baru' dan bukan petahana. Citra ini yang kemudian diberitakan terus-menerus baik secara langsung maupun tidak langsung sehingga masyarakat pembaca melihat Husein bukan bagian yang harus dikritisi dalam pemerintahan Mardjoko. Cara tersebut berhasil melepaskan Husein dari label 'incumbent'.

Selain itu, ketika masa pemerintahan Mardjoko komunikasi politik yang dibangun oleh Husein memang lebih lunak dibanding dengan sang bupati. Jika Mardjoko lebih suka melakukan konfrontasi dalam menyelesaikan persoalan baik yang sifatnya personal maupun terkait pelayanan publik, misalnya yang dengan terkait penyelesaian Pedagang Kaki Lima di Jalan Jenderal Soedirman, tidak demikian dengan Husein. Husein lebih memilih jalan yang kooperatif dalam menyelesaikan persoalan publik. Dalam persoalan PKL misalnya, Husein lebih memilih merelokasi para PKL. Komunikasi politik yang kurang baik yang dibangun oleh Mardjoko pada masa pemerintahannya banyak membuat masyarakat maupun aktivis LSM tidak lagi menaruh simpati terhadapnya.

Jika pada pemilukada sebelumnya tim yang khusus menangani media pasangan Mardjoko-Husein adalah yang satu-satunya paling kuat, justru di pemilukada 2013 Husein-Budhi memiliki tim media yang sama kuat atau relatif berimbang dalam iklan maupun pemberitaan dengan Mardjoko. Apalagi tim media dalam hal ini wartawan yang masuk sebagai tim sukses Husein-Budhi mayoritas adalah tim media yang ikut memenangkan Mardjoko-Husein dulu. Dalam hal pemberitaan, pada satu bulan sebelum pemilihan sempat muncul isu SARA untuk menggembosi suara Husein-Budhi melalui isu Budhi yang keturunan Tionghoa dan Non-muslim. Akan tetapi persoalan tersebut bisa diatasi dengan sigap oleh tim sukses Husein-Budhi dengan menghadirkan Budhi pada salah satu acara yang diselenggarakan oleh Muhammadiyah.

Citra baik lain yang diusung oleh pasangan Husein-Budhi adalah bersih dari politik uang. Berlawanan dengan tim Mardjoko yang terkenal dengan modal finansial yang paling banyak yang bisa digunakan untuk melakukan suap calon pemilih. Untuk memastikan bahwa tim Mardjoko-Gempol tidak melakukan suap kepada calon pemilih, tim sukses Husein-Budhi membentuk Satgas Anti Money Politics yang ternyata sangat efektif untuk menghambat aksi suap politik. Persepsi yang berkembang di masyarakat adalah bahwa yang akan melakukan suap politik adalah tim Mardjoko. Hasil dari Jaringan Survei Indonesia adalah masyarakat di Banyumas hanya 30 persen yang menerima uang dan yang menerima uang kemudian memilih calon kepala daerah tersebut jumlahnya kecil.

\section{Faktor kontekstual}

Faktor kontekstual merupakan sebab yang mendukung kemenangan Husein-Budhi di luar usaha yang dilakukan oleh pasangan itu. Artikel ini memberi penekanan pada faktor yang dapat mempengaruhi perilaku memilih warga dalam pemilukada. Perilaku memilih didasarkan pada gagasan bahwa situasi dan kondisi pemilih (baik internal maupun eksternal) bisa menjelaskan cara dan pola mereka dalam memilih sekaligus pada saat yang sama mempengaruhi sikap dan pilihan politik mereka terhadap persoalan-persoalan ekonomi, sosial maupun politik. Dalam konteks teori perilaku memilih, 
pendekatan yang menekankan faktor-faktor situasional dalam menjelaskan pilihan politik seseorang disebut dengan rational choice theory. Berdasarkan pendekatan ini, orang akan menentukan pilihan politiknya berdasarkan penilainnya terhadap isu-isu politik yang berkembang dan informasi seputar kandidat yang ada. Para pemilih akan menimbang secara rasional untuk membuat pilihan yang akan mendatangkan keuntungan buatnya.

Dalam konteks pemilukada Banyumas 2013, mayoritas pemilih menyaksikan sejumlah kejadian dan pemberitaan yang membentuk kekecewaan mereka terhadap Mardjoko. Salah satu kekecewaan masyarakat terhadap Mardjoko, yang mungkin berkontribusi terhadap kekalahannya, adalah kegagalannya mewujudkan pendirian pabrik bioetanol di Purwokerto. Dalam salah satu kampanyenya, dia sempat menyampaikan bahwa "sehari setelah dilantik saya akan langsung tandatangani izin pembangunan pabrik bioetanol yang bisa menyerap tenaga kerja lebih dari 50 ribu". Kenyataanya, pendirian pabrik dibatalkan dengan alasan ketidakcukupan lahan. Kegagalan ini mungkin saja dinilai sebagai bentuk pengkhianatan Bupati kepada rakyat. Betapa tidak, sudah banyak kecamatan yang menanam singkong sebagai bahan baku bioetanol namun di tengah jalan proyek ini dibatalkan.

Kegagalan Mardjoko mendirikan pabrik bioetanol merupakan salah satu cacat serius dari jargonnya sebagai bupati, yaitu Banyumas Proinvestasi. Masalah lain yang ditimbulkan oleh jargon itu adalah pembangunan yang terlalu berpusat di perkotaan. Hal ini terbukti dengan maraknya pembangunan restauran, hotel, perumahan, dan infrastruktur lain yang mayoritas berpusat di kota. Masalahnya adalah nasib desa kemudian justru tidak jelas. Inovasi di bidang pembangunan fisik, lapangan kerja, dan pertanian juga cenderung terbengkalai. Model pembangunan seperti ini dapat mengakibatkan memusatnya arus modal dan pembangunan di suatu daerah dan kawasan khususnya perkotaan, tidak munculnya pusat-pusat pertumbuhan baru di desa, disparitas ekonomi antara desa dan kota dan kelangkaan akses publik terhadap sarana dan prasarana yang memadai.

Persoalan yang muncul di masyarakat dan cara menerjemahkan masalah dengan solusi yang diberikan oleh pemerintahan Mardjoko sedikit banyak memberi pelajaran pada masyarakat bahwa dia adalah sosok arogan dan tidak menepati janji. Investasi yang digadang-gadang oleh Mardjoko sebagai program yang mampu mendatangkan pendapatan asli daerah yang besar justru menimbulkan persoalan baru seperti kebutuhan lahan untuk membangun hotel dan perumahan yang harus menggusur para PKL dan lahan sawah produktif. Komunikasi politik Mardjoko yang kurang baik membuat masyarakat tidak suka dengannya. Dalam konteks teori pilihan rasional, para pemilih yang cerdas di Banyumas ini lebih memilih calon pemimpin yang kemungkinan akan nyata mewujudkan program kerjanya yang menyentuh kebutuhan dasar masyarakat seperti pendidikan dan kesehatan, dan bukan pemimpin seperti Mardjoko yang hanya berhenti pada janji-janji masa kampanye saja.

\section{Simpulan}

Simpulan dari penelitian ini adalah, pertama, calon bupati yang petahana sebagai wakil bupati, seperti Husein, harus melepaskan diri dari bayang-bayang statusnya sebagai orang nomor dua itu agar kritik terhadap kegagalan pemerintahan tidak juga tertuju kepadanya. Kedua, pemilihan isu kampanye sebaiknya disesuaikan dengan kelemahan lawan dan sasaran yang menjadi target utama kampanye. Dalam konteks kemenangan Husein-Budhi, kelemahan lawan adalah sejumlah kegagalan program Mardjoko, dan sasaran utama adalah masyarakat desa atau kalangan ekonomi lemah. Ketiga, pencitraan diri di media massa juga harus didukung dengan kemampuan pengakaran yang kuat di tingkat akar rumput. Hal itu dapat dilakukan dengan cara membangun jaringan dengan elemen-elemen masyarakat sipil. Keempat, selain urgensi pengakaran partai, pemilukada Banyumas 2013 juga menunjukkan kuatnya peran partai sebagai mesin pemenangan. Kuatnya peran partai itu mensyaratkan adanya konsolidasi internal partai yang mantap. Kelima, informasi tentang prestasi atau kegagalan calon petahana dapat mengkondisikan para pemilih untuk memilih atau tidak memilih calon petahana tersebut. 


\section{Daftar Pustaka}

Amirudin dan Bisri AZ (2006) Pemilukada Langsung, Problem dan Prospek: Sketsa Singkat Perjalanan Pemilukada 2005. Yogyakarta: Pustaka Pelajar.

Cangara H (2009) Komunikasi Politik: Konsep, Teori, dan Strategi. Jakarta Rajawali: Pers, Fitriyah (2005) Sistem dan proses pemilukada secara langsung. Jurnal Analisis CSIS 34(3).

Firmanzah (2010) Mengelola Partai Politik. Jakarta: Yayasan Obor.

Firmanzah (2009) Marketing Politik. Jakarta: Yayasan Obor.

Purwoko (2005) Isu-isu strategis pemilukada langsung: Ekspresi kedaulatan untuk mewujudkan kesejahteraan rakyat. Jurnal Swara Politika 1, April 2005.

Romli (2005) Pemilukada langsung, otonomi daerah dan demokrasi lokal. Jurnal Analisis CSIS 34(3):279. 